\title{
Persistent Hypoxemia during Extracorporeal
Membrane Oxygenation in Delayed Diagnosed Paraquat Intoxication
}

\section{Gecikmiş Tanılı Paraquat Intoksikasyonunda Ekstrakorporeal Membran Oksijenasyonu Sırasında Dirençli Hipoksemi}

Nermin Kelebek Girgin, Nurdan Ünlü, Işık Şenkaya Sığnak, Remzi İşçimen, Ferda Kahveci, Hadi Çağlayan

\section{Abstract}

Paraquat is a highly toxic herbicide used in agriculture worldwide that causes progressive pulmonary fibrosis (PF) due to selective accumulation in the lungs. Paraquat intoxication can result in death due to multi-organ failure within a few days or respiratory failure due to PF within a few weeks. Veno-venous extracorporeal membrane oxygenation ( $V-V$ ECMO) is currently a widely used therapeutic strategy for acute respiratory distress syndrome (ARDS). Presently described is case of a 46-year-old man who was hospitalized with ARDS and treated with V-V ECMO. Expected oxygenation levels could not be attained despite ECMO support. When excluding causes for hypoxia in this patient on ECMO, detailed medical history revealed exposure to paraquat 3 weeks previously. Severe hypoxemia persisted during V-V ECMO and the patient died on sixth day after admission. The aim of this study was to examine probable causes of persistent hypoxemia during $\mathrm{V}-\mathrm{V}$ ECMO observed in this case.

Key words: Paraquat intoxication, extracorporeal membrane oxygenation, hypoxemia.

\section{Özet}

Paraquat, tarımda yaygın kullanılan ve akciğerlerde birikimi sonucu ilerleyici pulmoner fibrozise neden olan toksik özelliği yüksek bir herbisiddir. Paraquat intoksikasyonunda birkaç gün içinde çoklu organ yetmezliği veya birkaç hafta içinde pulmoner fibrozise bağlı solunum yetmezliği sonucu ölüm gelişebilir. Veno-venöz ekstrakorporeal membran oksijenasyonu ( $V-V$ ECMO) günümüzde akut solunum sıkıntısı sendromunda (ARDS) yaygın olarak uygulanan bir tedavi stratejisidir. Bu yazıda ARDS tanısı ile yatırılan ve tedavi sürecinde V-V ECMO kullanılan bir olguyu sunduk. ECMO desteğine rağmen yeterli oksijenasyona ulaşılamayan ve ECMO'ya bağlı hipoksi nedenleri dışlanan olguda, tekrar sorgulanan tıbbi öyküsü sonucu üç hafta önce paraquat maruziyeti olduğu saptandı. V-V ECMO desteğine rağmen hipoksi devam eden olgu, yoğun bakıma yatışının 6. günü kaybedildi. Bu olgu aracılığı ile V-V ECMO sırasında dirençli hipoksinin nedenlerini gözden geçirmeyi amaçladık.

Anahtar Sözcükler: Paraquat intoksikasyonu, ekstrakorporeal membran oksijenasyonu, hipoksemi.

Department of Anesthesiology and Reanimation, Uludağ Universi- Uludağ Üniversitesi Tıp Fakültesi, Anesteziyoloji ve Reanimasty, Faculty of Medicine, Bursa, Turkey yon Anabilim Dalı, Bursa

Submitted (Başvuru tarihi): 17.11.2016 Accepted (Kabul tarihi): 07.02.2017

Correspondence (iletişim): Nermin Kelebek Girgin, Department of Anesthesiology and Reanimation, Uludağ University, Faculty of Medicine, Bursa, Turkey

e-mail: nkelebek@uludag.edu.tr 
Paraquat, a compound containing $1,1^{\prime}$-dimethyl-4,4' bipyridinium dichloride, is an herbicide widely used in agriculture. Exposure to toxic doses can be fatal, despite aggressive medical intervention $(1,2)$. Early toxicity includes oral, pharyngeal, esophageal, and bowel ulcerations, and necrosis, acute kidney injury, and liver failure. Late toxicity is due to retention of paraquat in alveolar macrophages, where it reacts with highly abundant oxygen to form free radicals and reactive oxygen species (2). Death may occur due to multi-organ failure or respiratory insufficiency as a result of pulmonary fibrosis (PF) $(1,2)$. Hypoxia, which occurs secondary to many diseases, is a common sign in critically ill patients. Veno-venous extracorporeal membrane oxygenation ( $V$ - $V$ ECMO) in acute respiratory distress syndrome (ARDS) is currently a widely used therapeutic strategy $(3,4)$. In this treatment, blood is drained from the superior or inferior vena cava and reinfused into the right atrium. Artificial lung membrane adequately removes blood carbon dioxide and provides oxygenation (3). It allows use of protective mechanical ventilation strategy and reduces risk of barotrauma, volutrau$\mathrm{ma}$, ventilator-induced lung injury, or oxygen toxicity $(3,4)$. In some patients, however, extracorporeal support fails to restore arterial oxygenation (5).

Presently described are probable causes of persistent hypoxemia during V-V ECMO in case of paraquat intoxication that was diagnosed late.

\section{CASE}

A 46-year-old man weighing $70 \mathrm{~kg}$ who had consumed an herbicide 3 weeks prior and hidden that fact from health professionals presented at health center with sore throat. Oropharyngeal examination revealed purulent fibrin layers that bled when removed. White blood cell (WBC) count was $18,300 / \mu \mathrm{L}$ and C-reactive protein (CRP) level was $12 \mathrm{mg} / \mathrm{dL}$; antibiotic therapy was initiated on an outpatient basis. As the patient also developed weakness and shortness of breath, he was re-evaluated and found to have WBC count of $23,600 / \mu \mathrm{L}, \mathrm{CRP}$ level of $44 \mathrm{mg} / \mathrm{dL}$ and chest radiography showed bilateral infiltration. He was hospitalized in department of chest diseases with diagnosis of pneumonia and noninvasive mechanical ventilation and antibiotherapy were initiated. During treatment, urea and creatinine levels increased and hemodialysis was performed after diagnosing acute kidney injury. Renal condition subsequently improved; however, respiratory distress progressively worsened. The patient was intubated and transferred to intensive care unit (ICU) with diagnosis of primary ARDS due to pneumonia.

On admission to ICU, the patient's hemodynamic parameters were as follows: noninvasive blood pressure, 140/80 mm Hg; heart rate, 110 bpm; and body temperature, $36.6^{\circ} \mathrm{C}$. Arterial blood gas analyses yielded following results: $\mathrm{pH}, 7.31 ; \mathrm{PaO}_{2}, 64 \mathrm{~mm} \mathrm{Hg}$ on mechanical ventilation (fraction of inspired oxygen $\left[\mathrm{FiO}_{2}\right]$ : 1.0); $\mathrm{Pa}$ $\mathrm{CO}_{2}, 53 \mathrm{~mm} \mathrm{Hg} ; \mathrm{HCO}_{3}, 26 \mathrm{mmol} / \mathrm{L} ; \mathrm{SaO}_{2}, 90 \%$; lactate, $14 \mathrm{mg} / \mathrm{L}$ (normal range: $4-20 \mathrm{mg} / \mathrm{L}$ ). Acute Physiology and Chronic Health Evaluation II score was 22. Bilateral diffuse pulmonary infiltrates were detected on chest $X$-ray (Figure 1). Despite invasive mechanical ventilation with high $\mathrm{FiO}_{2}$ and positive end-expiratory pressure (PEEP) $\left(\mathrm{FiO}_{2}\right.$ : 1.0; PEEP: $\left.10 \mathrm{~cm} \mathrm{H} \mathrm{H}_{2} \mathrm{O}\right)$, hypoxemia and hypercarbia continued in following hours; therefore, the patient was placed in prone position. Subsequently, oxygenation improved based on arterial blood gas analysis (Table 1).

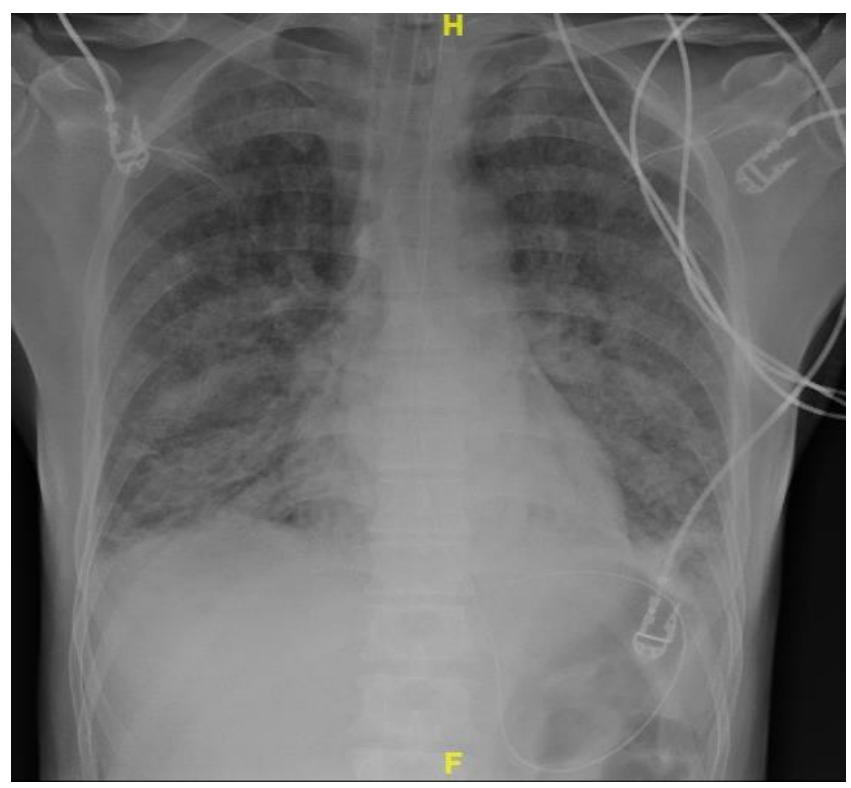

Figure 1: Chest radiography demonstrated bilateral lung infiltrates

On fourth day after admission, V-V ECMO (Maquet, Rastatt, Germany) was emergently initiated due to severe hypoxemia. Femoro-jugular approach was attempted, but jugular cannulation could not be performed. Pneumothorax occurred inadvertently, necessitating thorax tube insertion. A femoro-femoral approach was subsequently used, in which both drainage $(23 \mathrm{~F}, 38 \mathrm{~cm})$ and return $(21 \mathrm{~F}, 55 \mathrm{~cm}$ ) cannula were inserted through the femoral veins (Figure 2). However, expected oxygenation levels could not be attained, despite V-V ECMO support (Table 1). Blood gas evaluation from ECMO output line revealed $\mathrm{pH}$ of $7.61, \mathrm{pO}_{2}$ of $631 \mathrm{~mm} \mathrm{Hg}$, and $\mathrm{pCO}_{2}$ of 31 $\mathrm{mm} \mathrm{Hg}$; concurrent arterial blood gas sample revealed 
$\mathrm{pH}$ of $7.49, \mathrm{pO}_{2}$ of $46 \mathrm{~mm} \mathrm{Hg}$, and $\mathrm{pCO}_{2}$ of $44 \mathrm{~mm} \mathrm{Hg}$. These findings indicated serious problem with oxygen metabolism. On questioning the patient's family further to elicit information on any relevant medical history, it was learned that he had attempted suicide by consuming herbicide containing paraquat (Gramoxone; Syngenta AG, Basel, Switzerland) 3 weeks earlier and had hidden this fact from the previous health center. Moreover, the patient's family did not share this information before because they did not associate his recent health condition with the earlier paraquat exposure. Quantity of paraquat consumed could not be ascertained. Pulse steroids $(1 \mathrm{~g}$ methylprednisolone) and cyclophosphamide $(15 \mathrm{mg} / \mathrm{kg} / \mathrm{d})$ were initiated for paraquat-induced PF that caused ARDS. Transplantation center was informed about the case. Despite ECMO support, the patient died on sixth day after admission.

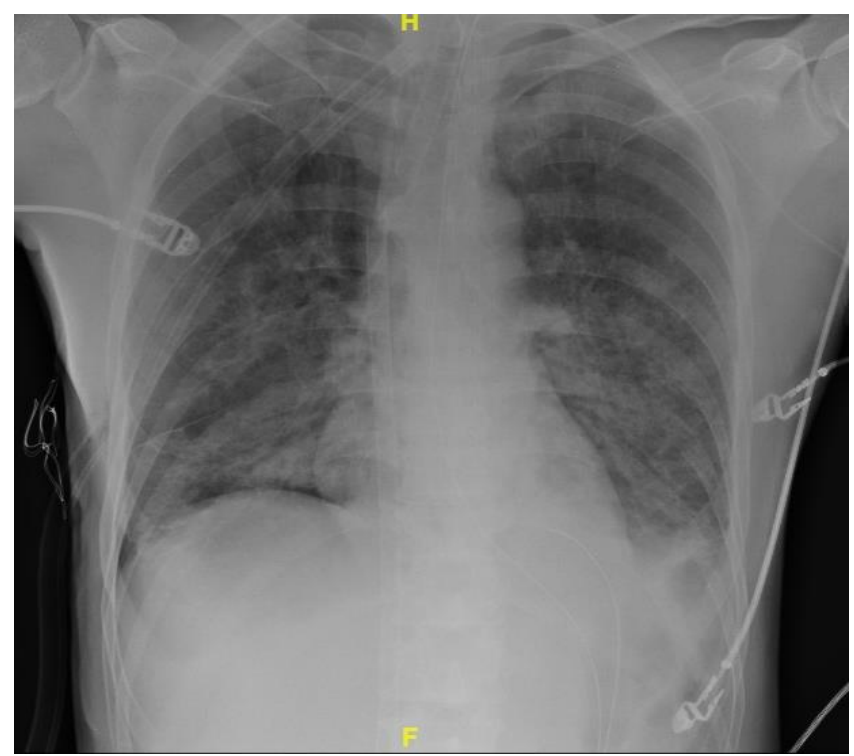

Figure 2: Chest radiography image taken during extracorporeal membrane oxygenation treatment

\section{DISCUSSION}

Paraquat toxicity is a major health problem in developing countries due to the lack of effective treatment, resulting in high mortality rate (overall mortality $>50 \%$ ) (6). Typically, severity and prognosis of acute poisoning are determined by amount of ingested toxin $(1,6,7)$. Following ingestion, paraquat has been shown to cause significant damage to multiple organs, including the lungs, liver, kidneys, and myocardium $(1,2,6)$. Renal failure commonly resolves within a few weeks, but lung injury is progressive, even if only a small quantity is ingested. Paraquat is actively taken up through the highly-developed polyamine uptake system, which ultimately leads to PF and respirato- ry failure $(6,8)$. In this case, although we could not ascertain exact quantity of paraquat ingested, it must have been large enough to cause severe PF.

After ingestion, paraquat is rapidly distributed to all organs and tissues, particularly the lungs. Paraquat concentration in the lungs is more than 10 times plasma concentration. It has been suggested that lung damage is primarily due to oxidative mechanisms (7). Paraquatinduced toxicity is a manifestation of its ability to undergo redox cycling and subsequent generation of reactive oxygen species that can cause direct cellular damage, or react further to form other reactive oxygen species and nitrite radicals. Redox cycling consumes nicotinamide adenine dinucleotide phosphate (NADPH), a key component of cell's antioxidant defense reaction. Resultant oxidative stress created by production of free radicals and depletion of NADPH directly causes cell damage (lipid peroxidation, mitochondrial toxicity, and apoptosis) $(6,7)$. Overall, it progressively causes lung damage due to edema, hemorrhage, interstitial inflammation, and fibrosis $(6,7)$. Hence, excessive oxygen supplementation can worsen pulmonary injury by increasing formation of oxygen free radicals $(2,3,7)$. Since the patient had concealed history of paraquat exposure, high $\mathrm{FiO} 2$ levels were used for both mechanical ventilation and ECMO to treat severe hypoxemia. This may have progressively worsened existing pulmonary pathology.

Although specific treatment for paraquat intoxication has not been established, early gastric lavage, administration of adsorbents, renal detoxification with hemoperfusion, immunosuppressive therapy, and lung transplantation have been attempted to reduce mortality $(2,6,7)$. However, efficacies of these therapeutic methods remain uncertain (6). Since this patient was admitted to ICU in late phase of intoxication, only appropriate therapy possible was immunosuppression. Immunosuppression is widely used as treatment for paraquat poisoning. Theory behind treatment is that since paraquat leads to acute inflammatory response, interference may inhibit subsequent processes that lead to lung fibrosis and death (6). Most widely studied regimen uses cyclophosphamide, methylprednisolone, and dexamethasone. Zhang et al. (7) reported 3 patients who had ingested large amounts of paraquat and survived after combined therapy with hemoperfusion, cyclophosphamide, and glucocorticoid. We used cyclophosphamide and methylprednisolone, but they could only be administered late in the course of the disease in our patient. 
Table 1: Mechanical ventilation parameters and arterial blood gas analysis of the patient

\begin{tabular}{|c|c|c|c|c|c|c|c|c|c|c|}
\hline & $\begin{array}{c}\text { ICU } \\
\text { admission }\end{array}$ & Day 1 & Day 2 & Day 3 & Day 3 & $\begin{array}{l}\text { Day } 4 \\
\text { ECMO } \\
1^{\text {st hour }}\end{array}$ & $\begin{array}{l}\text { Day } 4 \\
\text { ECMO } \\
8^{\text {th }} \text { hour }\end{array}$ & $\begin{array}{c}\text { Day } 5 \\
\text { ECMO } \\
18^{\text {th }} \text { hour }\end{array}$ & $\begin{array}{c}\text { Day } 5 \\
\text { ECMO } \\
24^{\text {th }} \text { hour }\end{array}$ & $\begin{array}{c}\text { Day } 5 \\
\text { ECMO } \\
36^{\text {th }} \text { hour }\end{array}$ \\
\hline Position & Supine & Supine & Prone & Supine & Prone & Supine & Supine & Supine & Supine & Supine \\
\hline MV Mode & PCV & PCV & PCV & PCV & PCV & PCV & PCV & PCV & PCV & PCV \\
\hline Respiratory rate & 12 & 20 & 18 & 18 & 18 & 14 & 12 & 12 & 12 & 14 \\
\hline $\mathrm{TV}(\mathrm{mL})$ & 400 & 520 & 580 & 560 & 560 & 650 & 660 & 600 & 580 & 600 \\
\hline PEEP $\left(\mathrm{cmH}_{2} \mathrm{O}\right)$ & 8 & 10 & 12 & 12 & 15 & 16 & 16 & 16 & 16 & 16 \\
\hline $\mathrm{FiO}_{2}$ & 1.0 & 1.0 & 1.0 & 0.9 & 1.0 & 1.0 & 1.0 & 1.0 & 1.0 & 1.0 \\
\hline $\mathrm{pH}$ & 7.31 & 7.13 & 7.32 & 7.24 & 7.42 & 7.49 & 7.43 & 7.46 & 7.41 & 7.38 \\
\hline $\mathrm{PaO}_{2}(\mathrm{mmHg})$ & 64 & 75 & 56 & 78 & 51 & 46 & 59 & 53 & 45 & 56 \\
\hline $\mathrm{PaCO}_{2}(\mathrm{mmHg})$ & 53 & 90 & 63 & 75 & 48 & 44 & 41 & 40 & 43 & 47 \\
\hline $\mathrm{HO}_{3}(\mathrm{mEq} / \mathrm{L})$ & 26 & 23 & 28 & 32 & 31 & 33 & 26 & 28 & 82 & 84 \\
\hline $\mathrm{BE}(\mathrm{mmol} / \mathrm{L})$ & 0.1 & -1.1 & 4.6 & 5 & 6 & 10.3 & 2.9 & 4.5 & 3.2 & 2.1 \\
\hline $\mathrm{SaO}_{2}(\%)$ & 90 & 89 & 87 & 92 & 86 & 91 & 90 & 85 & 82 & 84 \\
\hline $\begin{array}{l}\text { Lactate* } \\
\text { (mg/dL) }\end{array}$ & 14 & 6.8 & 11.4 & 13 & 18.9 & 18 & 23 & 24.9 & 22 & 20.7 \\
\hline $\mathrm{BP}^{\#}(\mathrm{mmHg})$ & $152 / 99$ & $\begin{array}{l}107 / 59 \\
160 / 91\end{array}$ & $\begin{array}{l}115 / 69 \\
180 / 94\end{array}$ & $\begin{array}{l}169 / 87 \\
174 / 94\end{array}$ & $\begin{array}{l}135 / 72 \\
161 / 89\end{array}$ & $92 / 40$ & $154 / 84$ & $121 / 70$ & $116 / 73$ & $84 / 50$ \\
\hline $\mathrm{HR}^{\#}$ (beat/min) & 116 & $\begin{array}{l}110 \\
134\end{array}$ & $\begin{array}{l}90 \\
114\end{array}$ & $\begin{array}{l}90 \\
114\end{array}$ & $\begin{array}{l}102 \\
109\end{array}$ & 100 & 95 & 104 & 119 & 119 \\
\hline $\mathrm{T}^{\#}(0 \mathrm{C})$ & 36.4 & $\begin{array}{l}36.5 \\
36.7\end{array}$ & $\begin{array}{c}36.4 \\
37\end{array}$ & $\begin{array}{l}36.4 \\
36.9\end{array}$ & $\begin{array}{l}37.3 \\
37.8\end{array}$ & 36.6 & 36.6 & 36.5 & 36.5 & 36.6 \\
\hline
\end{tabular}

ICU: intensive care unit, ECMO: extracorporeal membrane oxygenation, MV: mechanical ventilation, PVC: pressure-controlled ventilation,

TV: tidal volume, PEEP: positive end-expiratory pressure, BE: base excess. * Normal lactate levels: $4-20 \mathrm{mg} / \mathrm{dL}$.

BP: blood pressure, HR: heart rate, T: temperature.

\#These are minimum and maximum values at day 1, day 2 and day 3 (during supine and prone position).

Best prognostic marker for toxicity is plasma paraquat concentration. However, facilities for its measurement may not be readily available in most hospitals because of expensive equipment and associated technical problems $(1,7)$. In our patient, we could not measure plasma levels of paraquat due to technical difficulties.

Persistent hypoxemia encountered during initial period of ECMO support indicated that there could be serious problem with oxygen metabolism. Subsequently, we learned of paraquat exposure. There are other possible causes for severe hypoxemia during V-V ECMO (5). Schmidt et al. (9) described interactions between cardiac output (CO) and ECMO blood flow. They have recommended $\mathrm{ECMO}$ blood flow to $\mathrm{CO}$ ratio greater than 0.6 as an index for ECMO efficiency. Hence, it is suggested that the setting of ECMO blood flow is $60-80 \mathrm{~mL} / \mathrm{kg}$ to guarantee an oxygen delivery of $3 \mathrm{~mL} / \mathrm{kg} / \mathrm{min}$ (10). However, in sepsis or hyperthermia, $\mathrm{CO}$ is typically elevated; $\mathrm{CO}$ reduction can be considered to optimize ECMO blood flow to $\mathrm{CO}$ ratio. During veno-venous bypass, oxygenated blood is returned to venous circulation and mixed with systemic venous blood. Some of the mixed blood returns to extracorporeal circuit, and this recirculation ratio can reduce efficacy of ECMO support (recirculation ratio [\%] $=$ [oxygen saturation in drainage cannula - oxygen saturation in the superior vena cava] $\times 100 /$ [oxygen saturation in return cannula - oxygen saturation in the superior vena cava]) (5). Main mechanism of hypoxemia during ARDS is intrapulmonary shunt. Therefore, modulation of pulmonary shunt may help improve oxygenation during ECMO support (pulmonary shunt [\%] = [content of oxygen in pulmonary capillary blood sample - 
content of oxygen in venous blood sample] $\times 100 /$ [content of oxygen in venous blood sample - content of oxygen in arterial blood sample]) (5). Lastly, not surprisingly, oxygenator dysfunction can also cause persistent hypoxemia. In our case, ECMO blood flow fluctuated between 4500 and $5000 \mathrm{~mL} / \mathrm{min}$. Although $\mathrm{CO}$ level was not measured in our study, precordial echocardiography was performed and revealed normal heart function. In addition, no increase in oxygen consumption (e.g., due to sepsis or hyperthermia) was noted. ECMO output line $\mathrm{pO}_{2}$ was $631 \mathrm{~mm} \mathrm{Hg}$; hence, oxygenator dysfunction was ruled out. Even though it is possible that recirculation ratio was high because of femoro-femoral approach, it was not measured in that context at time of evaluation (pulmonary artery and superior vena cava catheters were not used). Recannulation was not considered after failed femoro-jugular attempt. Markedly severe pulmonary shunting because of progressive PF was noted. Since residual lung function was not optimal, the patient did not respond to recruitment maneuvers. However, we believe that deficient oxygen utilization due to the patient's primary problem played significant role in failure of ECMO support.

ECMO has been used successfully as a bridge to lung transplantation in paraquat intoxication (11). In our case study, ECMO was initiated as rescue therapy for ARDS, and diagnosis was established after its initiation.

Despite poor outcome in our case study, ECMO support should be considered as a bridge to lung transplantation in paraquat intoxication, as previously shown (11). In addition, if ECMO is unable to provide desired oxygenation level, ECMO pump flow, oxygenator function, CO, recirculation ratio, and pulmonary shunting should be taken into consideration. In addition, etiological factors that adversely affect oxygen metabolism, such as paraquat exposure, should be considered carefully.

\section{CONFLICTS OF INTEREST}

None declared.

\section{AUTHOR CONTRIBUTIONS}

Concept - N.K.G., N.Ü., I.S.S., R.I., F.K., H.Ç.; Planning and Design - N.K.G., N.Ü., I.S.S., R.I., F.K., H.Ç.; Supervision - N.K.G., N.Ü., I.S.S., R.İ., F.K., H.Ç.; Funding -; Materials - H.Ç., I.S.S.; Data Collection and/or Processing - N.K.G., N.Ü., R.I.; Analysis and/or Interpretation - R.I., H.Ç., F.K.; Literature Review - N.Ü., N.K.G.; Writing - N.K.G.; Critical Review - I.S.S., F.K.

\section{YAZAR KATKILARI}

Fikir - N.K.G., N.Ü., I.S..S., R.I., F.K., H.Ç.; Tasarım ve Dizayn - N.K.G., N.Ü., I.Ş.S., R.I., F.K., H.Ç.; Denetleme - N.K.G., N.Ü., I.Ş.S., R.I., F.K., H.Ç.; Kaynaklar -; Malzemeler - H.Ç., I.Ş.S.; Veri Toplama ve/veya İşleme N.K.G., N.Ü., R.I.; Analiz ve/veya Yorum - R.I.., H.Ç., F.K.; Literatür Taraması - N.Ü., N.K.G.; Yazıyı Yazan N.K.G.; Eleştirel İnceleme - I.S.SS., F.K.

\section{REFERENCES}

1. Liu XW, Ma T, Qu B, Ji Y, Liu Z. Prognostic value of initial arterial lactate level and lactate metabolic clearance rate in patients with acute paraquat poisoning. Am J Emerg Med 2013; 31:1230-5. [CrossRef]

2. Bertram A, Haenel SS, Hadem J, Hoeper MM, Gottlieb J, Warnecke $G$, et al. Tissue concentration of paraquat on day 32 after intoxication and failed bridge to transplantation by extracorporeal membrane oxygenation therapy. BMC Pharmacol Toxicol 2013; 6:14:45. [CrossRef]

3. Chiumello D, Brioni M. Severe hypoxemia: which strategy to choose. Crit Care 2016; 20:132. [CrossRef]

4. Combes A, Bréchot N, Luyt CE, Schmidt M. Extracorporeal membrane oxygenation: beyond rescue therapy for acute respiratory distress syndrome? Curr Opin Crit Care 2017; 23:60-5. [CrossRef]

5. Nunes LB, Mendes PV, Hirota AS, Barbosa EV, Maciel AT, Schettino GP, et al; ECMO Group. Severe hypoxemia during veno-venous extracorporeal membrane oxygenation: exploring the limits of extracorporeal respiratory support. Clinics (Sao Paulo) 2014; 69:173-8. [CrossRef]

6. Gawarammana IB, Buckley NA. Medical management of paraquat ingestion. Br J Clin Pharmacol 2011; 72:74557. [CrossRef]

7. Zhang $Q$, Wu $W Z$, Lu $Y Q$, Wang $J Z$, Shang $A D$, Yao $F$, Chen $Y$. Successful treatment of patients with paraquat intoxication: three case reports and review of the literature. J Zhejiang Univ Sci B 2012; 13:413-8. [CrossRef]

8. AsI AS, Dadashzadeh P. Acute kidney injury in patients with paraquat intoxication; a case report and review of the literature. J Renal Inj Prev 2016; 5:203-6. [CrossRef]

9. Schmidt M, Tachon G, Devilliers C, Muller G, Hekimian $G$, Bréchot $N$, et al. Blood oxygenation and decarboxylation determinants during venovenous ECMO for respiratory failure in adults. Intensive Care Med 2013; 39:83846. [CrossRef]

10. Agerstrand $\mathrm{CL}$, Bacchetta MD, Brodie D. ECMO for adult respiratory failure: current use an evolving application. ASAIO J 2014; 60:255-62. [CrossRef] 
11. Walder B, Bründler MA, Spiliopoulos A, Romand JA. Successful single-lung transplantation after paraquat in- toxication. Transplantation 1997; 64:789-91. [CrossRef] 